ReVISTA de BIOLOGía TROPICAL

\title{
Aspergillus and Penicillium (Eurotiales: Trichocomaceae) in soils of the Brazilian tropical dry forest: diversity in an area of environmental preservation
}

\author{
Renan do Nascimento Barbosa ${ }^{1}$, Jadson Diogo Pereira Bezerra ${ }^{1}$, Phelipe Manoel Oller Costa ${ }^{1}$, \\ Nelson Correia de Lima-Júnior ${ }^{2}$, Ivana Roberta Gomes Alves de Souza Galvão ${ }^{3}$, Anthony \\ Alves dos Santos-Júnior ${ }^{3}$, Maria José Fernandes ${ }^{3}$, Cristina Maria de Souza-Motta ${ }^{1,3}$ \& \\ Neiva Tinti Oliveira ${ }^{1}$ \\ 1. Departamento de Micologia, Programa de Pós-Graduação em Biologia de Fungos, Universidade Federal de \\ Pernambuco, Av. Nelson Chaves s/n, CEP 50760-420, Recife, PE; renan.rnb@gmail.com, jadsondpb@hotmail.com, \\ phelipeoller@yahoo.com.br, netinti@hotmail.com \\ 2. Programa de Pós-Graduação em Ciências Biológicas-UFPE; nelsonradar2005@hotmail.com \\ 3. Micoteca URM-UFPE; ivanaggalvao@hotmail.com, anthonyalves1@hotmail.com, mariajf2005@hotmail.com, \\ cristina.motta@ufpe.br
}

Received 27-II-2015. Corrected 25-VII-2015. Accepted 26-VIII-2015.

\begin{abstract}
Soil is a complex biological system that plays a key role for plants and animals, especially in dry forests such as the Caatinga. Fungi from soils, such as Aspergillus and Penicillium, can be used as bioindicators for biodiversity conservation. The aim of this study was to isolate and identify species of Aspergillus and Penicillium in soil, from the municipalities of Tupanatinga and Ibimirim, with dry forests, in the Catimbau National Park. Five collections were performed in each area during the drought season of 2012, totaling 25 soil samples per area. Fungi were isolated by suspending soil samples in sterile distilled water and plating on Sabouraud Agar media plus Chloramphenicol and Rose Bengal, and Glycerol Dicloran Agar. Isolates were identified by morphological taxonomy in the Culture Collection Laboratory and confirmed by sequencing of the Internal Transcribed Spacer of rDNA. A total of 42 species were identified, of which 22 belong to the genus Aspergillus and 20 to Penicillium. Penicillium isolates showed uniform distribution from the collecting area in Tupanatinga, and the evenness indices found were 0.92 and 0.88 in Tupanatinga and Ibimirim, respectively. Among isolates of Aspergillus evenness, the value found in Tupanatinga (0.85) was very close to that found in Ibimirim (0.86). High diversity and low dominance of fungi in soil samples was observed. These results contributed to the estimation of fungal diversity in dry environments of the Caatinga, where diversity is decreasing in soils that have undergone disturbance. Rev. Biol. Trop. 64 (1): 45-53. Epub 2016 March 01.
\end{abstract}

Key words: Catimbau, Caatinga, fungi, richness, taxonomy.

Knowledge of tropical forests plays a key role in developing global strategies for biodiversity conservation. In Brazil, the tropical dry forest is known as Caatinga (Tupi language; caa $=$ forest and tinga $=$ white) owing to the predominant type of vegetation (Santos et al., 2012). The Caatinga is a unique ecosystem in Brazil, and despite its socioeconomic importance to the country, it is subject to intense natural resource exploitation and has been little studied and protected. According to the literature, only $14 \%$ of tropical forest studies are related to the biodiversity of the Caatinga, and $86 \%$ are conducted in humid regions (Sánchez-Azofeifa et al., 2005).

Soil is a dynamic and complex biological system, in which different organisms play key roles in the maintenance and survival of plant and animal communities. Fungi are the predominant soil microorganism in terms of 
biomass and a number of different species can be found in soil including the genera Aspergillus and Penicillium (Cruz, Santos, Lima, Moreira \& Souza-Motta, 2013; Oliveira, Cavalcanti, Fernandes, \& Lima, 2013). Those genera are widespread, occurring frequently in soils, and have important roles in the processes of biodeterioration, as well as significant importance in the medical field, because some of them are pathogenic to humans and other animals (Houbraken \& Samson, 2011; Pitt \& Hocking, 2009).

The characterization of the mycodiversity of soil will not only contribute to preservation strategies but also can be used for developing bioindicators of environmental changes associated with disturbances caused by management practices and pollutants (Lambais, Cury, Maluche-Baretta, \& Büll, 2005). The prospecting of fungi can lead to increased understanding and preservation of the sources of genetic diversity, increased understanding of the distribution patterns of microorganisms and the involvement of biodiversity in the functioning and sustainability of ecosystems (Øvreås, 2000).

Among the areas of importance in the Caatinga, is the Catimbau National Park (PARNA Catimbau), created in 2002. The PARNA Catimbau is distributed among the area municipalities of Buíque (12 438 ha), Tupanatinga (23 $540 \mathrm{ha}$ ) and Ibimirim (24 $809 \mathrm{ha}$ ) in the State of Pernambuco, Brazil. Its landscape consists of walls of colorful sandstone formations, and unique vegetation. It attracts large numbers of visitors each year (SNE, 2002), and this area has also been used by small farmers for extracting wood from the forest areas for subsistence or for sale to local businesses as fuel.

There has been some study on the fungi in PARNA Catimbau (Cruz et al., 2013; Oliveira et al., 2013); however, soil samples have covered only a small part of the Park in the municipality of Buíque. Thus, taking into account the rapid loss of biodiversity and the role of fungi in the balance of an ecosystem, it is necessary to extend the knowledge of fungi, as well as their distribution in areas not yet surveyed. Therefore the aim of this study was to gather information on the diversity and distribution of Aspergillus and Penicillium species in soils of the Catimbau National Park in Pernambuco, Brazil.

\section{MATERIALS AND METHODS}

Study site: Soil samples were collected in areas from the Catimbau National Park in Pernambuco, Brazil in the municipalities of

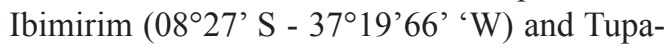
natinga $\left(08^{\circ} 29^{\prime} \mathrm{S}-037^{\circ} 19^{\prime} 58 \mathrm{~W}\right)$ during the drought season (July-November) of 2012. The vegetation of the park exhibits very different floristic and structural patterns, which comprise five distinct Caatinga vegetation types: shrub-arboreal; shrub with savannah elements; shrub with elements of rock fields; evergreen forest vegetation and shrub sub-evergreen (Rodal, Andrade, Sales \& Gomes, 1998). The municipality of Ibimirim shows traces of the practice of withdrawal of native vegetation for fuel and grazing activities, and includes homes of small farmers who make constant use of this soil. In the municipality of Tupanatinga, there is a greater amount of plant species typical of Caatinga, such as cacti Cereus jamacaru DC., Pilosocereus gounellei (FAC Weber) (Byles \& GD Rowley) and Melocactus zehntneri (Britton \& Rose) Luetzelb., and no grazing activities or housing. The soil sampled in the two collection areas was chemically analyzed in the Physics and Soil Fertility Laboratory of the Federal Rural University of Pernambuco (Table 1).

Soil sampling and processing: Five collections were performed in each area, and each collection was randomly assigned five 25 $\mathrm{m}^{2}$ quadrants $(5 \times 5 \mathrm{~m})$ with a minimum distance of $10 \mathrm{~m}$ between them. In each quadrant, six equidistant subsamples were collected at a depth of $0-20 \mathrm{~cm}$ and combined, consisting of a total of five mixed samples in each collection area. The samples were stored in labeled plastic bags, and manipulated in the Phytopathogenic Fungi Laboratory, Mycology Department, Center of Biological Sciences (CCB), Federal 
TABLE 1

Chemical properties of soils collected in the municipalities of Tupanatinga and Ibimirim in Brazilian tropical dry forest in the National Park Catimbau-Pernambuco, Brazil, in 2012

\begin{tabular}{|c|c|c|c|c|c|c|c|c|c|c|c|c|}
\hline \multirow{3}{*}{ Zone } & \multicolumn{12}{|c|}{ Chemical properties } \\
\hline & \multicolumn{5}{|c|}{$\mathrm{mg} \mathrm{dm}{ }^{3}$} & & \multicolumn{5}{|c|}{$\mathrm{cmol}_{\mathrm{c}} \mathrm{dm}^{3}$} & $\%$ \\
\hline & $\mathrm{Fe}$ & $\mathrm{Cu}$ & $\mathrm{Zn}$ & $\mathrm{Mn}$ & $\mathrm{P}$ & $\mathrm{pH}$ & $\mathrm{K}$ & $\mathrm{Na}$ & $\mathrm{Al}$ & $\mathrm{Ca}$ & $\mathrm{Mg}$ & MO \\
\hline Tupanatinga & 107.40 & 0.40 & 0.50 & 2.20 & 7 & 4.2 & 0.1 & 0.43 & 0.8 & 0.80 & 0.30 & 3.84 \\
\hline Ibimirim & 57.40 & 0.20 & 3.80 & 24.30 & 8 & 6.2 & 0.54 & 0.05 & 0.0 & 5.80 & 0.30 & 1.84 \\
\hline
\end{tabular}

Iron $(\mathrm{Fe})$, copper $(\mathrm{Cu})$, zinc $(\mathrm{Zn})$, manganese $(\mathrm{Mn})$, phosphorus $(\mathrm{P})$, potassium $(\mathrm{K})$, aluminum $(\mathrm{Al})$, calcium $(\mathrm{Ca})$, magnesium $(\mathrm{Mg})$, organic matter $(\mathrm{OM})$.

University of Pernambuco (UFPE), Pernambuco, Brazil. The soil collections were authorized by the Ministério do Meio Ambiente (MMA)/ Instituto Chico Mendes de Conservação da Biodiversidade (ICMBio); permission number: 33358-1/authentication code 39911643 issued on 22th march, 2012.

Fungal isolation: Fungi isolation from soil samples was carried out using a modified version of a serial dilution technique described by Clark (1965). In summary, $25 \mathrm{~g}$ of each soil sample was diluted in $225 \mathrm{~mL}$ of sterile distilled water. One milliliter of the $10^{-3}$ dilution was spread onto Sabouraud Agar with chloramphenicol (0.17 g/L), Bengal Rose (0.05 $\mathrm{g} / \mathrm{L}$ ) and Dicloran Glycerol (DG-18). The Petri dishes were incubated at $28 \pm 2{ }^{\circ} \mathrm{C}$ for 3 days. After incubation, the colonies were subcultured to Malt Agar and chloramphenicol $(0.17 \mathrm{~g} / \mathrm{L})$ was added until single colonies were obtained.

Fungal identification: The fungi were identified in the research laboratory of the Culture Collection (URM), Mycology Department, Universidade Federal de Pernambuco, Brazil, using specific methodology and literature described in Jurjević et al. (2012), Klich (2002), Pitt (1991),

Samson and Frisvad (2004), Samson and Houbraken (2011). Isolates with unclear morphological identification were selected for molecular identification. The genomic DNA extraction was performed according GóesNeto, Loguercio-Leite and Guerrero (2005).
The polymerase chain reaction (PCR) amplification for region ITS1-5.8S-ITS2 of rDNA was carried out with the primers ITS1 (5'-TCC GTA GGT GAA CCT GCG G-3') and ITS4 (5'-TCC TCC GCT TAT TGA TAT GC-3') according to White, Bruns, Lee and Taylor (1990). All amplification reactions were carried out in volumes of $25 \mu \mathrm{L}$ with $19 \mu \mathrm{L}$ PCR buffer (Tris-HCl $20 \mathrm{mM} \mathrm{pH} \mathrm{8.4;} \mathrm{NH4),} 2.0 \mathrm{mM}$ $\mathrm{MgCl} 2,0.20 \mathrm{mM}$ dNTP mix, $0.40 \mathrm{lM}$ of each primer, $0.04 \mathrm{U} / \mu 1$ Taq DNA polymerase (Fermentas Life Sciences), 25 ng DNA and sterile ultra-pure water up to $30 \mu \mathrm{l}$. Amplification was carried out in a thermocycler programmed for $8 \mathrm{~min}$ at $95{ }^{\circ} \mathrm{C}$ initial denaturation followed by 35 cycles of $30 \mathrm{~s}$ at $95{ }^{\circ} \mathrm{C}, 45 \mathrm{~s}$ at $47{ }^{\circ} \mathrm{C}$ and $3 \mathrm{~min}$ at $72{ }^{\circ} \mathrm{C}$, and $10 \mathrm{~min}$ final extension at $72{ }^{\circ} \mathrm{C}$.

The PCR products were checked in $1 \%$ agarose gel electrophoresis for 30-35 $\mathrm{min}$ at $100 \mathrm{~V}$. The amplification product obtained was purified with GenJET PCR Purification Kit - Fermentas ${ }^{\circledR}$. All PCR products were sent to Plataform of Sequencing-LABCEN/CCB (UFPE) to be sequenced. The sequences obtained were analysed in GenBank with BLASTn to search for similarity with the sequences deposited. Molecular operational taxonomic units (MOTUs) were defined using a $98 \%$ ITS region identity threshold.

Ecological analyses: After the identification of the filamentous fungal species from the different soils, ecological indices were applied: species richness consisted of the total number 
of species (S) in a unique sample. The distribution of each fungal species was calculated for each sampling using the following formula: $\mathrm{Di}=(\mathrm{Ni} / \mathrm{N}) * 100$, where $\mathrm{Di}=$ distribution of the species; $\mathrm{Ni}=$ number of colony forming units (CFU) of the species; $\mathrm{N}=$ total number of CFU. According to this formula, the species frequencies can be classified as: $<0.5 \%=$ rare, $\geq 0.5<1.5 \%=$ occasional, $\geq 1.5<3.0 \%$ = common, $\geq 3.0 \%=$ abundant $($ Schnittler $\&$ Stephenson, 2000). Means were compared by Tukey's test at $5 \%$ significance level using the ASSISTAT 7.7. Species Richness, ShannonWiener's Diversity, Pielou's Equitability and Berger-Parker's Dominance were calculated using the PAST 1.7 software (Hammer, Harper, \& Ryan, 2001).

\section{RESULTS}

A total of $3139 \times 10^{6}$ colony forming units per gram of soil (CFU/g) were found in the municipalities studied. Isolates numbering 2531 originated from Tupanatinga and 608 from Ibimirim, distributed across 42 species: 22 belonging to the genus Aspergillus and 20 to the genus Penicillium. The species, number of CFUs and the relative abundance (\%) are shown in Table 2. The species A. aureoterreus, A. lentulus, A. niveus, $A$. pulvinus, $A$. ruber, $A$. westerdijkiae, $P$. implicatum, $P$. janczewskii, $P$. restrictum, $P$. vinaceum occurred only in Tupanatinga soils while $A$. recurvatus was isolated only in soil samples from Ibimirim. Considering the total obtained in the two areas in relation to the classification of relative abundance according Schnittler \& Stephenson (2000), 14 $\%$ of the isolates were classified as rare (Di: < $0.5 \%), 26 \%$ occasional ( $\mathrm{Di} \geq 0.5<1.5 \%), 29$ $\%$ common ( $\mathrm{Di} \geq 1.5<3.0 \%$ ) and $31 \%$ were abundant ( $\mathrm{Di} \geq 3.0 \%$ ). Analyzing each collection area separately, $21 \%$ of the species were rare, $17 \%$ occasional, $26 \%$ common and $33 \%$ abundant in Tupanatinga and $02 \%$ were considered rare, $29 \%$ occasional, $19 \%$ common and $26 \%$ abundant in Ibimirim (Table 2).

Aspergillus and Penicillium genera contain a high number of species, many of which are very similar morphologically. Thus, species with dubious identification were extracted DNA and amplified ITS region and $\beta$-tubulin. Fifteen Molecular Operational Taxonomic Units (MOTUs) were identified based on the sequencing of the ITS region of rRNA with nucleotide differences from the other fungal sequences deposited in GenBank (National Center for Biotechnology Information, Bethesda, Maryland, USA) ranging from 1 to $2 \%$. The numbers of accesses in the GenBank are: A. tamarii (KM613134); A. westerdijkiae (KM613135); A. caelatus (KM613136); A. niveus (KM613137); A. aculeatus (KM613138); A. niger (KM613139); A. caelatus (KM613140); A. versicolor (KM613141); A. lentulus (KM613142); A. viride-nutans (KM613143); A. aureolus (KM613144); $A$. terreus (KM613145); P.simplicissimum (KM613146); P. adametzii (KM613147) and P.citrinum (KM613148).

Comparing the two collection areas, it was possible to obtain a large number of Colony Forming Units x $10^{3} \mathrm{~g} \mathrm{solo}^{-1}$ (CFUs) of Aspergillus (1 143) and Penicillium (1388) in Tupanatinga, and small number of CFUs Aspergillus (235) and Penicillium (373) in Ibimirim, (F $=6.236, \mathrm{p}=0.001$ and $\mathrm{F}=5.149, \mathrm{p}=0.001$ respectively); however, it was not possible to observe a significant difference in density between the genera in the same area by Tukey test at $5 \%$ probability.

The ecological indices indicated that the values of diversity and richness of Aspergillus and Penicillium species are close between the studied areas. The distribution of Aspergillus species showed greater uniformity in Ibimirim with an evenness index 0.86. However, Penicillium to the soil showed greater evenness in Tupanatinga with a value of 0.92 (Table 3 ). This result may be related to the density found for each collection site.

\section{DISCUSSION}

Most species found in this study are already known to occur in soils in Caatinga; however, A. aureolus, A. aureoterreus, A. caelatus, A. 
TABLE 2

Colony Forming Units, absolute frequency (fa) and relative abundance (\%) of species of Aspergillus and Penicillium isolated from soils in the municipalities of Tupanatinga (A) and Ibimirim (B) in Brazilian tropical dry forest in the National Park Catimbau-Pernambuco, Brazil, in 2012

\begin{tabular}{|c|c|c|c|c|c|c|c|c|c|c|c|}
\hline \multirow[t]{2}{*}{ Táxon } & \multicolumn{2}{|c|}{$\begin{array}{l}\text { 1st occurrence for } \\
\text { Caatinga's soil }\end{array}$} & \multicolumn{3}{|c|}{ Tupanatinga } & \multicolumn{3}{|c|}{ Ibimirim } & \multicolumn{3}{|c|}{ Overall analysis } \\
\hline & A & B & $\mathrm{fa}$ & $\%$ & Clas. & fa & $\%$ & Clas. & $\mathrm{fa}$ & $\%$ & Clas. \\
\hline Aspergillus aculeatus Iizuka & & & 130 & 5.14 & A & 23 & 3.78 & A & 153 & 4.87 & A \\
\hline A. allahabadii B.S. Mehrotra \& Agnihotri & & & 63 & 2.49 & $\mathrm{C}$ & 11 & 1.81 & $\mathrm{C}$ & 74 & 2.36 & $\mathrm{C}$ \\
\hline A. aureolus Fennell \& Raper & $\mathrm{X}$ & $\mathrm{X}$ & 14 & 0.55 & $\mathrm{O}$ & 7 & 1.15 & $\mathrm{O}$ & 21 & 0.67 & $\mathrm{O}$ \\
\hline A. aureoterreus Thom \& Raper & $\mathrm{X}$ & & 25 & 0.99 & $\mathrm{O}$ & 0 & 0.00 & - & 25 & 0.80 & $\mathrm{O}$ \\
\hline A. caelatus BW Horn & $\mathrm{X}$ & $\mathrm{X}$ & 7 & 0.28 & $\mathrm{R}$ & 10 & 1.64 & $\mathrm{C}$ & 17 & 0.54 & $\mathrm{O}$ \\
\hline A. flavus Link & & & 154 & 6.08 & A & 4 & 0.66 & $\mathrm{O}$ & 158 & 5.03 & A \\
\hline A. fumigatus Fresen & & & 55 & 2.17 & $\mathrm{C}$ & 14 & 2.30 & $\mathrm{C}$ & 69 & 2.20 & $\mathrm{C}$ \\
\hline A. insuetus (Bainier) Thom \& Church & & & 5 & 0.20 & $\mathrm{R}$ & 5 & 0.82 & $\mathrm{O}$ & 10 & 0.32 & $\mathrm{R}$ \\
\hline A. lentilus Balajee \& K.A. Marr & $\mathrm{X}$ & & 21 & 0.83 & $\mathrm{O}$ & 0 & 0.00 & - & 21 & 0.67 & $\mathrm{O}$ \\
\hline A. nidulans Fennell \& Raper & $\mathrm{X}$ & $\mathrm{X}$ & 9 & 0.36 & $\mathrm{R}$ & 4 & 0.66 & $\mathrm{O}$ & 13 & 0.41 & $\mathrm{R}$ \\
\hline A. niger Tiegh & & & 160 & 6.32 & A & 43 & 7.07 & A & 203 & 6.47 & A \\
\hline A. niveus Blochwitz & & & 1 & 0.04 & $\mathrm{R}$ & 0 & 0.00 & - & 1 & 0.03 & $\mathrm{R}$ \\
\hline A. pulvinus Kwon-Chung \& Fennell & & & 53 & 2.09 & $\mathrm{C}$ & 0 & 0.00 & - & 53 & 1.69 & $\mathrm{C}$ \\
\hline A. recurvatus Raper \& Fennell & & $\mathrm{X}$ & 0 & 0.00 & - & 6 & 0.99 & $\mathrm{O}$ & 6 & 0.19 & $\mathrm{R}$ \\
\hline A. ruber Thom \& Church & $\mathrm{X}$ & & 4 & 0.16 & $\mathrm{R}$ & 0 & 0.00 & - & 4 & 0.13 & $\mathrm{R}$ \\
\hline A. sydowii (Bainier \& Sartory) Thom \& Church & & & 6 & 0.24 & $\mathrm{R}$ & 2 & 0.33 & $\mathrm{R}$ & 8 & 0.25 & $\mathrm{R}$ \\
\hline A. tamarii Kita & & & 155 & 6.12 & A & 19 & 3.13 & A & 174 & 5.54 & A \\
\hline A. terreus Thom & & & 71 & 2.81 & $\mathrm{C}$ & 22 & 3.62 & A & 93 & 2.96 & $\mathrm{C}$ \\
\hline A. versicolor (Vuill.)Tirab. & & & 11 & 0.43 & $\mathrm{R}$ & 6 & 0.99 & $\mathrm{O}$ & 17 & 0.54 & $\mathrm{O}$ \\
\hline A. violaceofuscus Gasperini & & & 73 & 2.88 & $\mathrm{C}$ & 52 & 8.55 & A & 125 & 3.98 & A \\
\hline A. viridinutans Ducker \& Thrower & $\mathrm{X}$ & $\mathrm{X}$ & 77 & 3.04 & A & 7 & 1.15 & $\mathrm{O}$ & 84 & 2.68 & $\mathrm{C}$ \\
\hline A. westerdijkiae Frisvad \& Samson & $\mathrm{X}$ & & 49 & 1.94 & $\mathrm{C}$ & 0 & 0.00 & - & 49 & 1.56 & $\mathrm{C}$ \\
\hline Penicillium adametzii K.M. Zalessky & & & 89 & 3.52 & $\mathrm{~A}$ & 53 & 8.72 & $\mathrm{~A}$ & 142 & 4.52 & A \\
\hline P. aurantiogriseum Dierckx & & & 119 & 4.70 & $\mathrm{~A}$ & 5 & 0.82 & $\mathrm{O}$ & 124 & 3.95 & A \\
\hline P. bilaiae Chalab & & & 32 & 1.26 & $\mathrm{O}$ & 6 & 0.99 & $\mathrm{O}$ & 38 & 1.21 & $\mathrm{O}$ \\
\hline P. citreonigrum Dierckx & & & 153 & 6.05 & $\mathrm{~A}$ & 19 & 3.13 & $\mathrm{~A}$ & 172 & 5.48 & A \\
\hline P. citrinum Sopp & & & 159 & 6.28 & $\mathrm{~A}$ & 44 & 7.24 & A & 203 & 6.47 & A \\
\hline P. corylophilum Dierckx & & & 138 & 5.45 & A & 14 & 2.30 & $\mathrm{C}$ & 152 & 4.84 & A \\
\hline P. decumbens Thom & & & 20 & 0.79 & $\mathrm{O}$ & 12 & 1.97 & $\mathrm{C}$ & 32 & 1.02 & $\mathrm{O}$ \\
\hline P. griseofulvum Dierckx & & & 95 & 3.75 & $\mathrm{~A}$ & 51 & 8.39 & $\mathrm{~A}$ & 146 & 4.65 & A \\
\hline P. implicatum Dierckx & & & 41 & 1.62 & $\mathrm{C}$ & 0 & 0.00 & - & 41 & 1.31 & $\mathrm{O}$ \\
\hline P. janczewskii Zaleski & & & 83 & 3.28 & $\mathrm{~A}$ & 0 & 0.00 & - & 83 & 2.64 & $\mathrm{C}$ \\
\hline P. janthinellum Biourge & & & 77 & 3.04 & $\mathrm{~A}$ & 4 & 0.66 & $\mathrm{O}$ & 81 & 2.58 & $\mathrm{C}$ \\
\hline P. miczynskii K.M. Zalessky Stolk \& D.B. Scott & $\mathrm{X}$ & $\mathrm{X}$ & 40 & 1.58 & $\mathrm{C}$ & 9 & 1.48 & $\mathrm{O}$ & 49 & 1.56 & $\mathrm{C}$ \\
\hline P. minioluteum Dierckx & & & 57 & 2.25 & $\mathrm{C}$ & 62 & 10.20 & A & 119 & 3.79 & A \\
\hline P. restrictium J.C. Gilman \& E.V. Abbott & & & 99 & 3.91 & A & 0 & 0.00 & - & 99 & 3.15 & A \\
\hline P. sclerotiorum Beyma & $\mathrm{X}$ & $\mathrm{X}$ & 66 & 2.61 & $\mathrm{C}$ & 9 & 1.48 & $\mathrm{O}$ & 75 & 2.39 & $\mathrm{C}$ \\
\hline P.simplicissimum (Oudem.)Thom & & & 10 & 0.40 & $\mathrm{R}$ & 11 & 1.81 & $\mathrm{C}$ & 21 & 0.67 & $\mathrm{O}$ \\
\hline P. spinulosum Thom & & & 26 & 1.03 & $\mathrm{O}$ & 48 & 7.89 & $\mathrm{~A}$ & 74 & 2.36 & $\mathrm{C}$ \\
\hline P. verruculosum Peyronel & & & 55 & 2.17 & $\mathrm{C}$ & 16 & 2.63 & $\mathrm{C}$ & 71 & 2.26 & $\mathrm{C}$ \\
\hline P. vinaceum J.C. Gilman \& E.V. Abbott & & & 23 & 0.91 & $\mathrm{O}$ & 0 & 0.00 & - & 23 & 0.73 & $\mathrm{O}$ \\
\hline P. waksmanii K.M. Zalessky & & & 6 & 0.24 & $\mathrm{R}$ & 10 & 1.64 & $\mathrm{C}$ & 16 & 0.51 & $\mathrm{O}$ \\
\hline TOTAL & & & 2531 & 100 & & 608 & 100 & & 3139 & 100 & \\
\hline
\end{tabular}

Classification of species occurrence: rare (R), occasional $(\mathrm{O})$, common $(\mathrm{C})$ and abundant $(\mathrm{A})$. 
TABLE 3

Species richness, Shannon-Wiener's Diversity (H'), Pielou's Equitability (J') and Berger-Parker's Dominance (d) of Aspergillus (A) and Penicillium (P) isolated from soils of the counties of Tupanatinga and Ibimirim in Catimbau National Park during the dry season of 2012

\begin{tabular}{lccccccccc} 
& \multicolumn{2}{c}{ Richness } & \multicolumn{2}{c}{ Diversity } & \multicolumn{2}{c}{ Equitability } & \multicolumn{2}{c}{ Dominance } \\
\multicolumn{1}{c}{ Zone } & $\mathrm{A}$ & $\mathrm{P}$ & $\mathrm{A}$ & $\mathrm{P}$ & $\mathrm{A}$ & $\mathrm{P}$ & $\mathrm{A}$ & $\mathrm{P}$ \\
Tupanatinga & 21 & 20 & 2.6 & 2.7 & 0.85 & 0.92 & 0.14 & 0.11 \\
Ibimirim & 16 & 16 & 2.4 & 2.4 & 0.86 & 0.88 & 0.22 & 0.17 \\
\hline
\end{tabular}

lentulus, $A$. nidulans, $A$. recurvatus, $A$. ruber, A. viridinutans, $A$. westerdijkiae, $P$. miczynskii and $P$. sclerotiorum are being referenced for the first time to this soil ecosystem. In the natural environment of Northeastern Brasil, several studies have shown the presence of species of the genera Aspergillus and Penicillium and others Acomycota, Basidiomycota e Mucoromycotina (Cavalcanti, Oliveira, Fernandes, \& Lima, 2006; Silva, Tiago, Mattos, Paiva, \& Souza-Motta, 2011).

Oliveira et al. (2013) researched filamentous fungi in soils of the Catimbau National Park (Buíque-PE, Brazil) and found a total of 85 taxa; 71 species of anamorphic fungi, eight Zygomycetes and six Ascomycota. The abundant genera were Aspergillus (28 taxa) and Penicillium (18). Cruz et al. (2013) also studied the diversity of Penicillium in soils of the Caatinga in Catimbau National Park, but only in one area and in soils of Atlantic Forest. They obtained a total of 370 isolates from soils of the National Park, with $P$. aurantiogriseum, $P$. glabrum and $P$. lividum being the most dominant species. The authors also noted that 14 species occurred only in soils of the Caatinga, including $P$. adametzii, $P$. citrinum, $P$. implicatum, $P$. janczewskii, $P$. minioluteum, $P$. spinulosum, $P$. verruculosum and $P$. waksmanii. All these fungi species also occurred in the present study, indicating their ability to thrive in dry environments.

We used a culture-based approach and the sequencing of ITS region of the rRNA gene clarifications regarding the morphology taxonomy. The ITS region was chosen because this region has the highest probability of allowing the successful identification of a broad range of fungi. The isolates that were selected for sequencing in this study that had their identification confirmed by analysis of molecular data, showed a maximum $2 \%$ divergence from any sequence in the GenBank. Nilsson, Kristiansson, Ryberg, Hallenberg and Larsson (2008) showed that $2 \%$ is an acceptable margin for intraspecific differences in Ascomycota sequences for the ITS rDNA region.

Aspergillus species of the Niger group were also well represented with $A$. niger being considered abundant in both areas. This species is widely distributed and is often found in dry regions. Its distribution is related to the climate, vegetation and soil. Klich (2002), when studying the biogeography of Aspergillus in samples of soil and leaf litter, noted that this fungi occurs more frequently in desert environments and that $A$. niger has been isolated more frequently in areas of cultivated soils and tropical forests. According to the same author, members of the Nidulantes section are rare in soils that have experienced anthropogenic influence, which corroborates with the results obtained in this study, which was isolated only one species of the Nidulantes section.

Penicillium species belonging to the section Citrine were also well represented in this survey. According to Monteiro (2012) the Citrine section commonly occurs in soils and is also good producers of secondary metabolites that may confer benefit by providing a competitive advantage when colonizing a new substrate.

The least abundant species found for the genus Aspergillus was A. niveus (0.03 \%) which were isolated only in Tupanatinga. For the genus Penicillium, the lowest abundance was of $P$. waksmanii $(0.51 \%)$ in the two 
collection areas. Several studies have shown that different plant species have the ability to select certain fungal communities (De Bellis, Kernaghan, \& Widden, 2007). De Bellis et al. (2007) studied the relationship between groups of soil fungi and plant communities in a boreal forest in Québec (Canada) and noted that the species of fungi were related to plant species and not to the chemical properties of the soil. However, it is noteworthy that the type of vegetation also influences the physicochemical properties and composition of soil organic matter. There are reports that plants can cause changes in soil properties that lead to complex interactions with vegetation and may influence the soil fungal community (Nielsen, Osler, Campbell, Burslem, \& van Der Wal, 2010).

In the presente study, those species were classified as abundant (34\%), common (26 $\%)$, rare (14\%) and ocasional (26\%). Oliveita et al. (2013) found a total density of $1150 \times 10^{3}$ CFU/g, with Aspergillus (18 species) and Penicillium (28) species classified as abundant.

Penicillium commune was not isolated in any of the soil samples and $P$. restrictum was only obtained from Tupanatinga. This is interesting because in both collection sites, the native vegetation remains in good condition. Studies have shown that fungi are found with densities ranging from $10^{4}$ to $10^{6}$ organisms per gram of soil (Blackwell, 2011). According Bononi (1998), in environments with high density populations of fungi, different types of ecological relationships among populations of fungi and/or other bodies are established.

In the present study, high diversity and low dominance of fungi was observed in soil from Ibimirim, confirming the affirmation of Brower and Zar (1984) that a community with high diversity will have low dominance. The diversity and dominance of the fungal populations in soils depend on the occurrence of specific habitats for certain species. The decrease in the diversity, richness and evenness and increasing dominance has been linked to levels of environmental stress. However, it is possible that there may be an increase in diversity with increasing stress level. At one point where the stress level is minimal, diversity is reduced owing to competitive exclusion between species. If the stress level continues to increase, the competition decreases, resulting in an increase in diversity. However, when the disturbance reaches high levels, elimination occurs between species and the diversity decreases again (Clarke \& Warwick, 1994).

The distribution of isolates among the identified species had become more uniform among isolates of Penicillium in Tupanatinga with evenness indices equal to 0.92 . However, among isolates of Aspergillus the evenness found in Tupanatinga was very close to that found in Ibimirim. This is probably due to the characteristics of the genus as well as the density of fungal isolates. Additionally, communities with high evenness tend to have low dominance among species, since the evenness measure is related to the distribution of sampled individuals with the number of species (Cullen, Rudran, \& Valladares-Padua, 2004).

De Fede, Panaccione and Sextone (2001) and Grayston, Grifftih, Mawdesley, Campebell, and Bardgett (2001) found that in soils with high organic matter content, the microbial population tends to remain more stable over a period, probably owing to the wealth of ecological niches and variety of carbon sources. In the present study, the highest content of organic matter in the soil was found in Tupanatinga, and the $\mathrm{pH}$ of the soils was acidic (Table 1), differing from Moreira and Siqueira (2006) who found that the soils of dry or semi-arid regions are usually alkaline.

In Brazil, most of the work has been carried out in humid environments, so the results of this research contribute to the provision of information on the diversity of fungi in soils of dry environments as well as on the mycodiversity of Caatinga soils. The microorganisms, including fungi, are the first organisms to demonstrate the effects of changes in an environment on large populations and on ease of dispersion, beyond the short generation time. The results suggest that the diversity of the fungal community in the soil may become reduced in soils that have undergone some 
sort of disturbance such as removal of native vegetation. Thus, the preservation of some impacted areas is essential for the resilience of the ecosystem. The isolation and identification of fungi in soils, as well as being fundamental to the taxonomic survey, can lead to the development of studies on the biotechnological potential of these organisms and their ecological relationship with the environment.

\section{ACKNOWLEDGMENTS}

This work was carried out with support from Conselho Nacional de Desenvolvimento Científico e Tecnológico (CNPq). We thank the Ministério do Meio Ambiente (MMA)/Instituto Chico Mendes de Conservação da Biodiversidade (ICMBio) for their permission to collect soil samples in the study area and the Mycology Department (CCB/UFPE) and Platform of Sequencing (LABCEN/CCB/UFPE) for the use of its facilities.

\section{RESUMEN}

Aspergillus y Penicillium (Eurotiales: Trichocomaceae) en suelos de un bosque seco tropical brasileño: diversidad en un área protegida. El suelo es un sistema biológico complejo, que desempeña un papel fundamental en las plantas y los animales, especialmente en los bosques secos como la Caatinga. Los hongos del suelo, tales como Aspergillus y Penicillium, pueden ser utilizados como bioindicadores para la conservación de la biodiversidad. El objetivo de este estudio fue aislar e identificar las especies de Aspergillus y Penicillium del suelo, en los municipios de Ibimirim y Tupanatinga en el Parque Nacional Catimbau. Cinco colecciones se llevaron a cabo en cada área durante la estación seca de 2012, un total de 25 muestras de suelos por área. Los hongos fueron aislados mediante la suspensión en agua destilada estéril y se sembraron en medio de cultivo Agar Sabouraud más Cloranfenicol y Rosa de Bengala, y también en el medio Agar Dicloran Glicerol. Los aislamientos fueron identificados en el Laboratorio de Colección de Hongos y se confirmaron por secuenciación del espaciador transcrito interno de ADN. Un total de 42 especies fueron identificadas, 22 de ellas pertenecientes al género Aspergillus y 20 al género Penicillium. Los aislamientos de Penicillium mostraron una distribución uniforme en Tupanatinga con índices de uniformidad entre 0.92 y 0.88 en Ibimirim. Entre los aislamientos de Aspergillus el valor encontrado en Tupanatinga (0.85) fue muy similar al encontrado en Ibimirim (0.86). Se observó una gran diversidad y bajo predominio de hongos en las muestras de suelo. Estos resultados contribuyen a la estimación de la diversidad de hongos en ambientes secos, especialmente en la Caatinga, donde la diversidad es decreciente en los suelos que han sufrido alteraciones.

Palabras clave: Catimbau, Caatinga, hongos, riqueza, taxonomía.

\section{REFERENCES}

Blackwell, M. (2011). The Fungi: 1, 2, 3...5, 1 million species? American Journal of Botany,98, 426-238.

Bononi, V. L. R. (1998). Zigomicetos, Basidiomicetos e Deuteromicetos: noções básicas de taxonomia e aplicações biotecnológicas. São Paulo: Instituto de Botânica, Secretaria de Estado e Meio Ambiente.

Brower, J. E., \& Zar, J. H. (1984). Community similarity. In J. E. Brower, \& J. H. Zar (Eds.), Field \& Laboratory for General Ecology (pp. 161-164). Dubuque, Iowa: W.C. Brown Publisher.

Cavalcanti, M. A. Q., Oliveira, L. G., Fernandes, M. J., \& Lima, D. M. (2006). Fungos filamentosos isolados do solo em municípios na região Xingó, Brasil. Acta Botanica Brasilica, 20, 831-837.

Clark, F. E. (1965). Agar-plate method for total microbial count. In C. A. Black, D. D. Evans, J. L. White, L. E. Ensminger, F. E. Clark, \& R. C. Dinaver (Eds.), Methods of soil analysis, Part 2. Chemical and microbiological properties (pp. 1460-1466). USA: American Society of Agronomy, Soil Science Society of America.

Clarke, K. R., \& Warwick, R. M. (1994). Changes in Marine Communities: an Approach to Statistical Analysis and Interpretation. Bournemouth. Plymouth Marine Laboratory. Bournemouth: Bourne Press Limited.

Cruz, R., Santos, C., Lima, J. S., Moreira, K. A., \& SouzaMotta, C. M. (2013). Diversity of Penicillium in soil of Caatinga and Atlantic Forest areas of Pernambuco, Brazil: an ecological approach. Nova Hedwigia, 97, 543-556.

Cullen, L. Jr., Rudran, R., \& Valladares-Padua, C. (2004). Métodos de estudo em biologia da conservação e manejo da vida silvestre. Brasil: Universidade Federal do Paraná.

De Bellis, T., Kernaghan, G., \& Widden, P. (2007). Plant community influences on soil microfungal assemblages in boreal mixed-wood forests. Mycologia, 99, 356-367.

De Fede, K. L., Panaccione, D. G., \& Sextone, A. J. (2001). Characterization of dilution enrichment cultures obtained from size-fractionated soil bacteria by BIOLOGR community-level physiological profiles and restriction analysis of $16 \mathrm{~S}$ rDNA genes. Soil Biology and Biochemistry, 33, 1555-1563. 
Góes-Neto, A., Loguercio-Leite, C., \& Guerrero, R. T. (2005). DNA Extraction from frozen field-collected and dehydrated herbarium fungal basidiomata: perform of SDS and CTAB-based methods. Biotemas, 18, 19-32.

Grayston, S. J., Grifftih, G. S., Mawdesley, J. L., Campebell, C. D., \& Bardgett, R. D. (2001). Accounting of variability in soil microbial communities of temperate upland grassland ecosystem. Soil Biology and Biochemistry, 33, 533-551.

Hammer, O., Harper, D. A. T., \& Ryan, P. D. (2001). PAST: Palaeontological Statistics software package for education and data analysis. Palaeontologia Electronica, 4, 1-9.

Houbraken, J., \& Samson, R. A. (2011). Phylogeny of Penicillium and the segregation of Trichocomaceae into three families. Studies in Mycology, 70, 1-51.

Jurjević, Z., Peterson, S. W., Stea, G., Solfrizzo, M., Varga, J., Hubka, V., \& Perrone, G. (2012). Two novel species of Aspergillus section Nigri from indoor air. IMA Fungus, 3, 159-173.

Klich, M. A. (2002). Biogeography of Aspergillus species in soil and litter. Mycologia, 94, 21-27.

Lambais, M. R., Cury, J. C., Maluche-Baretta, C. R. D., \& Büll, R. C. (2005). Diversidade Microbiana nos Solos: Definindo Novos Paradigmas. In P. VidalTorrado, L. R. F. Alleoni, M. Cooper, A. P. da Silva, \& E. J. Cardoso (Eds.), Tópicos em ciência do solo (pp. 43-84). Brasília: Sociedade Brasileira de Ciência do Solo.

Monteiro, M. C. P. (2012). Identificação de fungos dos gêneros Aspergillus e Penicillium em solos preservados do cerrado (Master Thesis). Universidade Federal de Lavra, Brasilia.

Moreira, F. M. S., \& Siqueira, J. O. (2006). Microbiologia e bioquímica do solo. Lavras: Universidade Federal de Lavras.

Nielsen, U. N., Osler, G. H. R., Campbell, C. D., Burslem, D. F. R. P., \& van Der Wal, R. (2010). The influence of vegetation type, soil properties and precipitation on the composition of soil mite and microbial communities at the landscape scale. Journal of Biogeography, 37, 1317-1328.

Nilsson, R. H., Kristiansson, E., Ryberg, M., Hallenberg, N., \& Larsson, K. H. (2008). Intraspecific ITS variability in the kingdom fungi as expressed in the international sequence databases and its implications for molecular species identification. Evolutionary Bioinformatics 4, 193-201.

Oliveira, L. G., Cavalcanti, M. A. Q., Fernandes, M. J. S., \& Lima, D. M. M. (2013). Diversity of filamentous fungi isolated from the soil in the semiarid area, Pernambuco, Brazil. Journal of Arid Environments, 95, 49-54.
Øvreås, L. (2000). Population and community level approaches for analysing microbial diversity in natural environments. Ecology Letters, 3, 236-251.

Pitt, J. I. (1991). A laboratory Guide to Common Penicillium Species. North Ryde: N.S.W: Commonwealth Scientific and Industrial Research Organization.

Pitt, J. I., \& Hocking, A. D. (2009). Fungi and Food Spoilage. Australia: Springer US

Rodal, M. J. N., Andrade, K. V. S., Sales, M. F., \& Gomes, A. P. S. (1998). Fitosociologia do componente lenhoso de um refúgio vegetacional no município de Buique, Pernambuco. Revista Brasileira de Biologia, 58, 517-526.

Samson, R. A., \& Frisvad, J. C. (2004). Penicillium Subgenus Penicillium: new Taxonomics Schemes, Mycotoxins and Other Extrolites. Studies in Myco$\log y, 49,1-260$.

Samson, R. A., \& Houbraken, J. (Eds.) (2011). Phylogenetic and taxonomic studies on the genera Penicillium and Talaromyces. Studies in Mycology, 7. The Netherlands: CBS-KNAW Fungal Biodiversity Centre.

Sánchez-Azofeifa, G. A., Quesada, M., Rodriguez, J. P., Nassar, J. M., Stoner, K. E., Castillo, A., Garvin, T., Zent, E. L., Calvo-Alvarado, J. C., Kalacska, M. E. R., Fajardo, L., Gamon, J. A., \& Cuevas-Reyes P. (2005). Research priorities for neotropical dry forests. Biotropica, 37, 477-485.

Santos, R. M., Oliveira-Filho, A. T., Eisenlohr, P. V., Queiroz, L. P., Cardoso, D. B. O. S., \& Rodal, M. J. N. (2012). Identity and relationships of the Arboreal Caatinga among other floristic units of seasonally dry tropical forests (SDTFs) of north-eastern and Central Brazil. Ecology and Evolution, 2, 409-428.

Schnittler, M., \& Stephenson, S. L. (2000). Myxomycetes biodiversity in four different forest types in Costa Rica. Mycologia, 92, 626-637.

Silva, D. C. V., Tiago, P. V., Mattos, J. L. S., Paiva, L. M., \& Souza-Motta, C. M. (2011). Isolamento e seleção de fungos filamentosos do solo de sistemas agroflorestais do Município de Bom Jardim (PE) com base na capacidade de produção de enzimas hidrolíticas. Revista Brasileira de Botânica, 34, 607-610.

SNE - Sociedade Nordestina de Ecologia. (2002). Projeto técnico para a criação do Parque Nacional do Catimbau/PE - versão final, em cumprimento ao contrato $n^{\circ}$ 086-00/02, subprojeto "Proposta para criação do Parque Nacional do Catimbau/PE”. Recife: Sociedade Nordestina de Ecologia (SNE).

White, T. J., Bruns, T., Lee, S., \& Taylor, J. (1990). Amplification and direct sequencing of fungal ribosomal RNA genes for phylogenetics. In M. A. Innis, D. H. Gelfand, J. J. Shinsky, \& T. J. White (Eds.), PCR protocols: A guide to methods and applications (pp. 315-322). San Diego: Academic. 
